\title{
The Economics of Lotteries: A Survey of the Literature
}

\author{
By \\ Kent R. Grote \\ and \\ Victor A. Matheson
}

August 2011

COLLEGE OF THE HOLY CROSS, DEPARTMENT OF ECONOMICS

FACULTY RESEARCH SERIES, PAPER NO. 11-09*

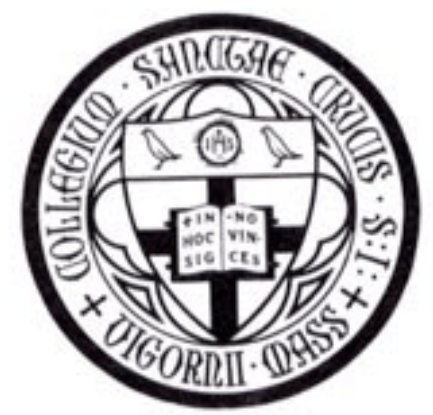

Department of Economics

College of the Holy Cross

Box 45A

Worcester, Massachusetts 01610

(508) 793-3362 (phone)

(508) 793-3710 (fax)

http://www.holycross.edu/departments/economics/website

*All papers in the Holy Cross Working Paper Series should be considered draft versions subject to future revision. Comments and suggestions are welcome. 


\title{
The Economics of Lotteries: A Survey of the Literature
}

\author{
By \\ Kent Grote ${ }^{\dagger}$ \\ Lake Forest College \\ and \\ Victor A. Matheson ${ }^{\dagger \dagger}$ \\ College of the Holy Cross
}

August 2011

\begin{abstract}
Lotteries represent an important source of government revenues in many states and countries, so they are of interest to public finance economists. In addition, lotteries provide researchers interested in microeconomic theory and consumer behavior with a type of experimental lab that allows economists to explore these topics. This paper surveys the existing literature on lotteries organized around these two central themes. The first section examines the microeconomic aspects of lotteries including consumer decision-making under uncertainty, price and income elasticities of demand for lottery tickets, cross-price elasticities of lottery ticket to each other and to other gambling products, consumer rationality and gambling, and the efficiency of lottery markets. The second section covers topics related to public finance and public choice including the revenue potential of lotteries, the tax efficiency and dead-weight loss of lottery games, the horizontal and vertical equity of lotteries, earmarking and the fungibility of lottery revenues, and individual state decisions to participate in participate in public lotteries.
\end{abstract}

JEL Classification Codes: D81, H71, L83

Keywords: lotto, lottery, public finance, gambling

\footnotetext{
${ }^{\dagger}$ Kent Grote, Department of Economics and Business, Lake Forest College, Lake Forest, IL 60045, 847-735-5196 (phone), 847-735-6193 (fax), grote@lfc.edu

$\AA^{\dagger}$ Victor A. Matheson, Department of Economics, Box 157A, College of the Holy Cross, Worcester, MA 01610-2395, 508-793-2649 (phone), 508-793-3710 (fax), vmatheso@holycross.edu
} 


\section{Introduction}

Lotteries represent one of the oldest and most common forms of gambling around the world with origins dating back at least to ancient Rome and possibly even earlier to the Han Dynasty of China in the second century B.C. A lottery involves the sale by an organizing body, typically the government but also occasionally private businesses or charities, of a ticket giving the possessor a potential monetary reward. Lotteries differ from casinos in that lottery ticket sales generally do not take place at a location specifically set aside for gambling, and modern lotteries are usually operated by governments instead of private firms.

Lotteries are of particular interest to scholars for a variety of reasons. First, they represent an important source of government revenues in many states and countries, so they are of interest to public finance economists. Second, lotteries provide researchers interested in microeconomic theory and consumer behavior with a type of experimental lab that allows economists to explore these topics. This paper surveys the existing literature on lotteries organized around these two central themes. The first section examines the microeconomic aspects of lotteries including consumer decision-making under uncertainty, price and income elasticities of demand for lottery tickets, cross-price elasticities of lottery ticket to each other and to other gambling products, consumer rationality and gambling, and the efficiency of lottery markets. The second section covers topics related to public finance and public choice including the revenue potential of lotteries, the tax efficiency and dead-weight loss of lottery games, the horizontal and vertical equity of lotteries including potential externalities associated with gambling, earmarking and the fungibility of lottery revenues, and individual state decisions to participate in participate in public lotteries. 
The current published literature regarding the economics of lotteries is extensive enough that is it impractical to cover every paper on the topic, but this paper covers a broad range of the most influential papers in the field. A more extensive bibliography of lottery related papers is available from the authors upon request or through www.repec.org.

\section{Microeconomics: Demand for Lottery}

Much of the literature on lottery markets focuses on the demand for lottery products, be it in the form of estimating demand equations, determining the regressive nature of ticket purchases, or discussing the concepts of consumer rationality and market efficiency. Indeed, why people demand lottery tickets in the first place is a real question. Friedman and Savage (1948) (and subsequently Markowitz (1952)) suggest that the curvature of individuals' utility functions changes as they get richer (or move away from their "normal" income) providing a theory for why individuals exhibit risky behavior through their participation in lottery markets at the same time that they exhibit risk averse behavior elsewhere. These theories provide motivation the idea that lottery purchases can be considered rational behavior and, if so, then consumers of lottery products should have typical demand functions that include some familiar microeconomic variables including price, income, consumer preferences, number of consumers, price of related products and product characteristics.

\section{Effective price}

The price of lottery tickets has received much attention in the literature, which may at first seem surprising since the actual price paid for tickets tends to remain constant unless the lottery authority decides to change it. The "effective price" of a lottery ticket, which considers 
the price as well as the return, however, may change over time and across lottery jurisdictions. Evidence on the effect of the effective price on ticket sales is mixed, with early studies (Vrooman 1976; Vasche, 1985; Mikesell, 1987) concluding that the effective price of tickets does not have a significant impact on the sales of tickets and later studies (DeBoer, 1986; Clotfelter and Cook, 1989; Miller and Morey, 2003) finding a significant and negative relationship between the takeout rate and lottery sales.

While earlier studies use the takeout rate (or "vigorish") to calculate the effective price, subsequent studies tend to use the difference between the nominal ticket price and the expected return as the measure of effective price. For many lottery games, there is no difference between the expected return and the net difference between the ticket price and the takeout; however, lotto is a common lottery game that is distinguished by the characteristic that if there is no jackpot winner in a given drawing period, the prize pool rolls over into the next drawing, increasing the potential jackpot in the next period. Higher jackpots typically lead to higher expected values for ticket purchases leading to lower effective prices even if the actual dollar price of a ticket remains constant. Because changes in game structures, ticket prices, and takeout rates are rare, many of the studies of lottery demand examine lotto games, taking advantage of the constant changes in effective price by including either jackpot or expected return as an explanatory variable.

Many studies of demand also estimate price elasticities in order to determine whether the existing lottery structures maximize the potential gaming revenues. Both Walker (1998) and Forrest, Gulley and Simmons (2000a) conclude the UK National Lottery has an optimal takeout rate of $50 \%$ based on an estimated price elasticity of demand that is close to -1 . Many other empirical studies also estimate that price elasticities are approximately equal to -1; however, 
there are studies that find relatively more elastic demand (Farrel and Walker (1999) and Farrell, Morgenworth and Walker (1999) for the U.K. lottery, particularly in the long-run, Papachristou and Karamais (1998) for the Greek Lotto, and Gulley and Scott (1993) for the Mass Millions game) implying a lower takeout rate would increase revenues. Other studies suggest relatively less elastic demand as low as -0.66 short-run price elasticity for the UK National Lottery as found by Forrest, Gulley and Simmons (2000a), -0.382 in the Taiwan lotto game as measured by Lee, Lin and Lai (2010), and -0.19 for the Mass Megabucks game as measured by Gulley and Scott (1993), implying higher takeout rates would increase government revenues.

Forrest, Simmons and Chesters (2002) argue that lottery demand depends more on jackpot size than expected value because players tend to participate in games with very low odds of winning in order to "dream big" about substantial winnings. Thus, studies such as those by DeBoer (1990) and Cook and Clotfelter (1993) include jackpot size and jackpot size squared to test for a non-linear and positive relationship between jackpot size and ticket sales. Jackpot rollovers are such a distinctive part of the literature in terms of measuring the effect of "price changes" that Forrest, Simmons and Chesters (2002), Papachristou (2006) and Geronikoulaou and Papachristou (2007) calculate a "jackpot elasticity of sales (demand)" that has a similar interpretation as price elasticity of demand, except with a positive expected relationship with ticket sales.

\section{Income elasticity}

Like the price of a product, income is another significant factor in the demand for any good and is particularly important for empirical studies on lotteries in order to determine whether the "lottery tax" in a particular jurisdiction is regressive. Studies typically use income level, per 
capita income, disposable income, or real income in order to estimate this effect, although some studies also use variables like the poverty rate in order to capture the regressive nature of lottery spending (Blalock, Just and Simon, 2007). While the measurements of income elasticity vary from study to study, empirical research uniformly finds income elasticities less than one, indicating that a relatively greater percentage of income is spent on lottery products at lower income levels (Suits, 1977; Clotfelter, 1979; Clotfelter and Cook, 1987, 1989). Instant games tend to have lower income elasticities than other games (Mikesell, 1989; Jackson, 1994; Garrett and Coughlin, 2009) while lotto games with large jackpots tend to appeal to more affluent customers. Indeed, Oster's (2004) study of Powerball sales in Connecticut predicts that at exceedingly high jackpot levels, the Powerball game could actually become progressive, the only such finding in the literature.

Other indirect measures of income also tend to suggest lotteries are a regressive form of taxation. Studies by Laitner (1999), Layton and Worthington (1999), and Coughlin and Garrett (2009) all find that individuals in government income assistance programs are more likely to participate in lottery markets. The observed effect of unemployment on ticket sales is mixed with Mikesell (1994) and Scott and Garen (1994) both finding that unemployment rates tend to have a positive impact on lottery ticket sales, while Blalock, Just and Simon (2007) find a negative relationship and DeBoer (1990) finds no correlation.

\section{Demographics}

Demographics also influence ticket sales, and empirical studies are in wide agreement as to the significant influences on ticket sales. The old adage that the lottery is a "tax on people who are bad at math" is borne out in the data. Level of education typically has a negative relationship 
with ticket sales (Clotfelter and Cook, 1987, 1989; Kitchen and Powells, 1991; Farrell and Walker, 1999). With respect to race and gender, studies tend to find that black and Hispanic individuals are more likely to buy lottery tickets than whites (Jackson, 1994; Scott and Garen, 1994), and men are more likely to play than women (Clotfelter and Cook, 1987, 1990; Kitchen and Powells, 1991; Farrell and Walker, 1999) although the effect can vary by location, time period, and type of game. Studies also find that people who live in urban areas and, therefore, are closer to more lottery vendors tend to buy more lottery tickets than people in rural areas (Hersch and McDougall, 1989; Clotfelter and Cook, 1989, 1993; Kitchen and Powells, 1991). Studies of other demographic variables such as age and marital status do not exhibit consistent effects on lottery ticket sales (Clotfelter and Cook, 1989, 1990; Kitchen and Powells, 1991; Jackson, 1994; Farrell and Walker, 1999).

\section{Other products: substitutes and complements}

Lottery authorities typically offer multiple games, and lotteries may coexist with other types of gambling, so a final issue relating to the demand for lottery tickets is the extent to which other products are complements or substitutes for lotteries. The literature provides mixed empirical results on this issue. Cook and Clotfelter (1993), Gulley and Scott (1993), and Forrest, Gulley and Simmons (2004) conclude that lotto rollovers do not impact sales of other lottery products in the lotteries they study. Mason, Steagall and Fabritius (1997) find that the two Florida lotto games are substitutes for one another, while Forrest, Gulley and Simmons (2004) find some substitution effects between scratchcard purchases and the Lotto in the U.K. Conversely, in Ireland, Purfield and Waldron (1999), and, across the U.S., Grote and Matheson (2006a), find that different lottery games serve as complements to one another. While it is more 
natural to suppose that lottery products are substitutes for one another, Grote and Matheson conclude that transactions costs and the ability to buy multiple types of game tickets at the same time are responsible for the complementarities exhibited by lottery ticket buyers.

A topic related to the concept of substitution is what happens to overall spending on lottery games in a lottery jurisdiction when new games are introduced. Presumably, the purpose of introducing new lottery games should be to increase overall lottery spending, but if new lottery games merely attract ticket sales from already existing games, an effect often referred to as "cannibalization," then the lottery authority has not benefited from introducing a new game to the lottery mix. Mikesell and Zorn (1987), Grote and Matheson (2006a), and Matheson and Grote (2007) all find that the introduction of new lotto games does have a negative impact on sales for existing lottery products, but the addition of new games increases overall lottery ticket sales. Matheson and Grote (2007) go on to note that the overall increase in ticket sales is larger if the new game is sufficiently different in odds or prize structure from the existing games. Finally, it is well-documented that the introduction of lotteries in neighboring states serves to reduce lottery spending within a state as people will cross state boundaries to buy lottery tickets (Suits, 1979; Mikesell and Zorn, 1987; Walker and Jackson, 1999; Garrett and Marsh, 2002).

Lottery ticket sales can also affect or be affected by the availability of other gambling activities in a jurisdiction. Some studies (Scott and Garen, 1994; Calcagno, Walker and Jackson, 2010) find that the presence of a lottery increases participation in other gambling activities such as casino gaming and dog and horse racing, presumably reflecting a general attitude or preference towards gambling in a society. Most of the literature on gambling activities and their relationship to lotteries, however, find that either they are unrelated to each other or that they are substitutes for one another. Walker and Jackson (2008) and Forrest, Gulley, and Simmons (2010) 
find that sales revenues in racing and lotteries are not strongly related to each other. Steinnes (1998) finds that casino gambling does not have a significant impact on lottery sales while Kearney (2005b) finds that lottery spending does not significantly reduce spending on other forms of gambling. The remaining studies tend to find that lotteries and other forms of gambling are substitutes for one another (Gulley and Scott, 1989; Siegel and Anders, 2001; Elliott and Navin, 2002).

\section{Microeconomics: Lottery Structure and Demand}

In addition to the other factors affecting demand for lottery tickets described in the previous section, other characteristics of lottery games including the odds of winning, the prize structure, and the payout rate of the game affect the demand for tickets as well. If consumers have preferences for certain lottery game characteristics, then it is logical to assume that states can and should structure their lottery games to attract the most consumers in order to maximize lottery revenues. This is often referred to in the literature as achieving an "optimal structure" for a lottery. A lottery association must determine a payout rate, the odds of winning, and the distribution of payouts among different size prizes for each game it offers.

While lotto games also offer smaller consolation prizes to ticket buyers who fail to win the largest prize, the jackpot prize is arguably the primary attraction of the game (Forrest, Simmons and Chesters, 2002), so it seems logical that states should structure the odds of winning the jackpot in order to attract the most consumers within a lottery district. Both DeBoer (1990) and Thiel (1991) conclude that the New York state lottery and Washington state lotteries, respectively, should provide worse odds of winning in order to attract more players to their lotto games. Longer odds would result in more rollovers leading to higher jackpots, and if consumers 
care more about the size of the lottery prize than they do about the odds of winning such a strategy will result in higher sales.

The ability of lottery associations to generate additional demand by lengthening the odds of winning the jackpot is not unlimited, however, as eventually the odds of winning the grand prize become so low that the jackpot is won too rarely causing players to lose interest (Forrest and Alagic, 2007). Thus, the optimal jackpot odds depend on how many potential consumers there are in the jurisdiction offering the tickets. Cook and Clotfelter (1993) refer to this as the "scale economies of lotto" and find that states often select their game formats so that the probability of winning the jackpot multiplied times the population within the state is approximately equal to one. Lottery associations have taken this finding to heart, and the past 20 years have witnessed a rise in multi-state or multi-country lotto games offering huge jackpots at increasingly long odds.

Cook and Clotfelter's findings are dependent on the particular risk preference of lottery consumers in the United States. Outside of the U.S., the question of the optimal odds of winning has also been studied in the U.K., Greece, and Spain. Walker and Young (2001) use simulations of sales for the U.K. Lotto to demonstrate that reducing the odds of winning may, in fact, reduce sales in the U.K. because reducing the odds of winning reduces the expected return on a lottery ticket, while increasing the variance and skewness of expected return, which may not be favorable to the risk preferences of consumers in the U.K. Papachristou (2009) demonstrates mathematically that scale economies likewise affect the mean, variance, and skewness of expected returns. Forrest, Perez, and Baker (2010) find that sales for the Spanish National Lotto game increase when the odds of winning decline and more lower tier prizes are added to the game structure. 
Aside from the odds of winning the jackpot, a second important characteristic of lottery games is the prize structure offered. While the jackpot prize may be of primary interest to purchasers of lottery tickets, it is not the only characteristic, and the prizes offered as well as the percentage of sales used to fund the prizes offered (the payout rate) may have an impact on consumer preferences and consumer demand. Quiggin (1991) provides a mathematical model of lottery demand which shows that, although smaller prizes do not have much impact on the overall expected value of a ticket, they do reduce the expected losses so that consumers may prefer lottery games with multiple prizes and prize levels. The model also suggests that product differentiation of lottery tickets is particularly important when consumers of lottery products have very different risk preferences.

A number of empirical studies have been offered in the literature to test Quiggin's propositions. Scoggins (1995) finds that Florida lottery officials should increase the percentage of sales allocated to the jackpot prize from $25 \%$ to $30 \%$ in order to increase sales. Garrett and Sobel (1999) finds that lottery players in 216 U.S. games in 1995 appear to be risk averse and favor skewness of returns, recommending that lottery providers can achieve more skewness by offering smaller consolation prizes along with larger jackpots. Conversely, Walker and Young (2001) recommend that the UK lotto game reallocate the funding of prize money from the jackpot to smaller prizes in order to stimulate demand. Demand for tickets should increase due to higher overall expected return and lower variance, which should offset the reduced skewness of returns. Garrett and Sobel (2004) perform a statistical study on 135 U.S. lottery games and conclude that ticket sales for these games only depend on the size and odds of winning the jackpot prize, not by the expected value of lower tier prizes. 
A final characteristic that receives substantial attention in the lottery literature is the optimal takeout rate of lottery games. A higher takeout rate means a larger percentage of the ticket price is kept as revenue but also means lower ticket sales if consumers are responsive to effective price. A lottery association will be maximizing revenues when the effective price elasticity of demand nears a value of -1 . Empirical tests of takeout rates have concluded that many lottery games approximate an optimal takeout rate, and researchers have been quick to recommend changes to takeout rates when effective price elasticities of demand deviate from the revenue maximizing figure. Refer to the previous section on effective price for more details. In one final contribution of note on this topic, Chen and Chie (2008) demonstrate that there is an associated Laffer curve based on the takeout rate (or lottery tax rate) that is flat at the top, concluding that this provides a rationale for the varying takeout rates offered by different lottery games since there is no single "optimal takeout rate" for all games.

\section{Behavioral Economics: Rationality and Market Efficiency in Lottery Markets}

While it is reasonable to question whether gambling by otherwise risk averse individuals can ever be considered rational, both Friedman and Savage (1948) and Markowitz (1952) offer theories about the shape of utility functions that establish a rational demand for lottery products across all income levels. Others justify gambling as rational by assuming gambling entails consumption benefits as well as expected winnings or losses (Conlisk, 1993). From these bases, rational participation in lottery markets can be tested empirically along with tests of efficiency in those markets. There are several different methods of testing for rationality in lottery markets that are related to the numbers that individuals choose to play, the consumer response to lottery 
rollovers and changes to the form of jackpot payouts, and where ticket buyers purchase their tickets, among others.

Related to the numbers selected, two particular types of irrational behavior are tested in lottery markets: the presence of the gambler's fallacy and the conscious selection of numbers. The gambler's fallacy occurs when players change their beliefs about the probability of a particular combination of numbers being drawn again after those numbers come up as the winning combination even though each drawing in the lottery is an independent random event (Vaughan Williams, 2005b). Clotfelter and Cook (1993), Terrell (1994), and Papachristou (2004) all find evidence of the gambler's fallacy in various games, finding that players tend to not play numbers that have recently won. Simon (1999), on the other hand, finds evidence of an overselection of recent winning numbers in the U.K. lottery. On a similar note, Guryan and Kearney (2006; 2008) find evidence of a "lucky store" effect in Texas. After a store sells a winning ticket, consumers increase their purchases of lottery tickets from anywhere from 12 to $38 \%$ at that store relative to other stores in the community, an effect that cannot be explained with rational behavior.

The conscious selection of numbers in lottery games has received even more attention in the literature. If people have preferences for certain combinations of numbers based on "lucky numbers" such as birthdays, multiples of 7 , or patterns on a play slip then certain combinations of numbers will be selected more frequently while other combinations will be relatively ignored. If prizes are pari-mutuel in nature, however, "lucky numbers" will actually result in lower payouts since consumers playing common numbers will have to share their winnings among more people, violating rationality. 
Conscious number selection has been widely identified in lottery games. Clotfelter and Cook (1989) note that lottery associations even encourage conscious selection in marketing related to their products perhaps to increase demand by players who wish to "control their destiny." Conscious selection also reduces the coverage of number combinations in any given draw, increasing the probability that a jackpot prize will roll over and potentially attracting additional sales in future draws in response to the higher advertised jackpots. Walker (1998), Simon (1999), Farrell, Hartley, Lanot and Walker (2000), and Hauser-Rethaller and Konig (2002) all find that conscious selection results in more rollovers in lotto games although the impact on ticket sales tends to be minor.

Other studies concentrate not on whether conscious selection occurs but whether its effect on expected returns is strong enough to allow individuals an opportunity to make money by betting on the unpopular numbers. While Papachristou and Karamanis (1998) do not find that conscious number selection in the Greek lotto is large enough so that unpopular numbers ever become a fair bet (i.e. a bet with a positive expected return), other studies of the Canadian Lotto (Ziemba, Brumelle, Gauier and Schwartz, 1986), Massachusetts numbers game (Chernoff, 1981), 6/49 Lotto games in the U.S. (Thaler and Ziemba, 1988), and the U.K. Lotto (Baker and McHale, 2009) all find potentially profitable bets among unpopular number combinations. All of the studies caution, however, that it is difficult to make profits over a reasonable timeline by playing these numbers because of the low odds of winning.

Other tests of consumer behavior relate to whether the bettors' responses to lottery rollovers are irrationally high (referred to as "lotto fever" or "lottomania") or irrationally low (referred to as "lotto apathy" or "jackpot fatigue"), and how lottery players' behavior changes immediately subsequent to the jackpot prize being won, a phenomenon known as the "halo 
effect." Lotto fever occurs when a jackpot rollover attracts enough additional purchases of tickets to actually reduce the expected return on a ticket in spite of the higher jackpot being offered due to the increased probability of having to share a jackpot prize should it be won. Beenstock and Haitovsky (2001) find statistical evidence of lotto fever consistently occurring after the third rollover in the Israel lotto game. Matheson and Grote $(2004 ; 2005)$ find that lotto fever is very rare in a cross-sectional study across U.S. lotto games, occurring in less than $0.1 \%$ of the drawings in their analyses of the phenomenon in over 17,000 and 23,000 drawings, respectively.

Lotto apathy occurs when tickets sales do not increase despite an increase in jackpot and the expected return. Matheson and Grote (2005) find lotto apathy to be a much more common experience in U.S. lotto games although it still occurs in less than $2 \%$ of the over 10,000 drawings examined and is concentrated in states that simultaneously offer both a high jackpot multi-state lotto game and a smaller in-state game whose jackpot can be easily overshadowed by the larger game. Similar to lotto apathy is the concept of "jackpot fatigue," the concept that lottery participants lose interest in the lottery, even at high jackpots, after the lottery has been around for a period of time. Most models of lottery demand include a time trend as an independent variable in order to explain lottery ticket sales (Vasche, 1985; Mikesell, 1987; Mikesell and Zorn, 1987; DeBoer, 1990). Beenstock and Haitovsky (2001) particularly comment on the fact that the lotto in Israel does not have a positive time trend in spite of a growing economy in that country. Creigh-Tyte and Farrell (2003) also offer that it is the declining trend in sales for the U.K. lottery that has encouraged Camelot to offer new lottery games and innovations to current games in order to keep the public interested in purchasing lottery tickets. 
Several papers examine the "halo effect," the tendency for ticket purchases immediately following the award of a large jackpot to be unexpectedly high despite the jackpot resetting to a lower level. The finding of a halo effect demonstrates a degree of irrationality among lotto players and can be seen as a type of gambling addiction. Farrell, Morgenworth and Walker (1999), Grote and Matheson (2007), and Guryan and Kearney (2010) all find degrees of addiction among various lotto games in the U.S. and U.K.

A final topic relating to bettor rationality is the consumers' understanding of lottery payouts. Atkins and Dyl (1995) demonstrate that individuals who win the lottery should choose the annuity, or the prize paid out over several years, rather than a lump-sum paid out immediately because of the tax implications of the two payouts. However, they conclude that most people will choose the lump-sum (a conclusion that is validated by the empirical evidence), arguably because a lump-sum can make them feel much wealthier, an argument consistent with Friedman and Savage's (1946) rationale for participating in lotteries in the first place. Irrespective of the wisdom of the lump sum versus the annuity, Matheson and Grote (2003) show that ticket buyers tend to be rational with respect to changes in the annuity lengths of jackpot prize payouts. They show that consumers are not fooled into buying more tickets when state lottery associations artificially increase advertised jackpots by increasing the annuity length of the prize payout.

\section{Market efficiency}

If consumers, as a whole, display rationality in lottery markets, then lottery markets should also tend to be efficient. Vaughan Williams (2005a; 2005b) discusses the concepts of weak form, semi-strong form and strong form efficiency in gambling markets in general as well 
as the empirical literature related to efficiency. Weak form efficiency is stated to exist when there are no betting opportunities in lottery markets that offer positive expected returns (which means that on net, there are no fair bets), and strong form efficiency exists when wagers have expected values of (1 minus the takeout rate) times the amount of the wager (Thaler and Ziemba, 1988). If players are rational there should be few if any opportunities for lotteries to violate weak form efficiency as the presence of a fair bet should attract more ticket purchases, reducing the expected value of a ticket back down to the ticket price (or lower). Aside from opportunities provided by purchasing rare number combinations discussed previously, studies covering a number of lotteries typically find that opportunities for fair bets when purchasing a single randomly selected ticket are rare or non-existent (Thaler and Ziemba, 1988; Krautman and Ciecka, 1993; Papachristou and Karamanis, 1998; Scott and Gulley, 1995; Ciecka, Epstein and Krautman, 1996; Grote and Matheson, 2006b). In the most expansive study, Matheson and Grote (2005) find fair bets in roughly $1 \%$ of the more than 23,000 drawings in U.S. state and multistate lotteries they examined with positive expected values occurring most frequently in minor games in smaller states where relatively high jackpots attract little consumer attention.

Numerous authors also examine the possibility of purchasing every number combination, a strategy dubbed the "trump ticket." In all cases, these studies find that the purchase of the trump ticket is far more likely to provide a fair bet than the purchase of a single ticket (Thaler and Ziemba, 1988; Ciecka, Epstein and Krautman, 1996; and Grote and Matheson, 2006b), a result mathematically proven by Matheson (2001). Matheson and Grote (2005) find $11 \%$ of all lottery drawing they examine would represent a fair bet with the purchase of the trump ticket, an astonishingly high number. They, like Thaler and Ziemba (1988), conclude, however, that this finding does not necessarily indicate a violation of weak form efficiency as the transactions costs 
involved in purchasing all possible combinations are too high to make this strategy feasible, creating an effective barrier to purchasing the trump ticket. Krautmann and Ciecka (1993) note that a consortium attempting to purchase every combination of a 1992 drawing in the Virginia lotto was unsuccessful in covering every combination despite enlisting help from numerous lottery retailers.

Tests for strong form efficiency in lottery markets are provided by Scott and Gulley (1995) and Forrest, Gulley and Simmons (2000b). Both papers find evidence in favor of strong form efficiency and conclude that bettors are able to accurately forecast sales for a lotto drawing. In addition, the ability to forecast improves with the number of draws that have taken place reaching a reasonable level of accuracy within the first 30 drawings of the game.

\section{Public Finance: Revenues and Efficiency of Lotteries}

As a significant contributor to government finances in the U.S. and the rest of the world, lotteries have been widely examined by public finance economists focusing primarily on their revenue potential and desirability as a method of taxation. Scholars generally acknowledge that even under the most optimistic assumptions, lotteries are unlikely to be able to provide more than a few percent of the revenue needs for a modern state or national government (Humphreys and Matheson, 2012; Mikesell and Zorn, 1986, 1988) although they frequently approach or exceed in magnitude tax collections on goods such as alcohol or tobacco. Unique among tax collection agencies, revenue maximization is an explicitly stated goal of lottery organizations, and numerous papers have explored ways in which variations in product variety, lottery structure, and payout rates could be adjusted to increase revenues. All of these topics have been discussed 
previously in the sections on demand for lottery and lottery structure and will not be repeated here.

The efficiency with which lotteries generate revenues is a topic of some debate. As first noted by Brinner and Clotfelter (1975), lotteries are an unusual form of taxation in that participation is voluntary, and the government actually creates the consumption good that is then taxed. The creation of a new consumption good should raise welfare even if dead-weight loss is created when the good is taxed (Rodgers and Stuart, 1995; Farrell and Walker, 1997). Livernois (1986) disputes the notion that lotteries should be considered voluntary since spending on lotteries simply substitutes for spending elsewhere in the economy, and Rodgers and Stuart (1995) note that while the creation of an untaxed lottery would raise welfare, the tax levels typically associated with state lotteries reduce welfare in comparison to other methods of taxation.

Aside from the high takeout rates of government lotteries, the large dead-weight loss of lottery taxation is also a result of high administrative costs, especially when payments to vendors (Mikesell and Zorn, 1988) and advertising expenses (Heberling, 2002) are considered. DeBoer (1985) and Caudill, Johnson, and Mixon (1995), however, stress that while administrative costs of lotteries are indeed relatively high, lottery associations generally experience economies of scale in lottery provision and average administrative costs per ticket can be reduced by pooling resources with other agencies and by expanding sales.

Both Mikesell and Zorn (1988) and Szakmary and Szakmary (1995) stress that an additional problem with lottery revenues is their volatility. Humphreys and Matheson (2012) counter that while lottery and gaming revenues may be subject to significant change from year to year, the variation in gaming revenues is negatively correlated with changes other common 
revenue sources so that lottery revenues as part of overall system of taxation serve to reduce the overall volatility of government revenues.

\section{Public Finance: Incidence, Equity, and Externalities of Lotteries}

One of the strongest criticisms of lotteries as a means of revenue collection is that they are highly regressive. Indeed, on this point there is universal agreement among economists. Much of the literature on the correlation between income and lottery purchases has been reviewed in the previous section on income elasticity, and it is not necessary to revisit it here. Many lottery studies focus specifically on the distributional incidence of lottery revenues instead of the general factors affecting lottery demand including Wisman (2006), Kearney (2005a; 2005b), Campbell and Finney (2005), and Combs, Kim and Spry (2008). Like those on general lottery demand, these studies uniformly find that lotteries represent a highly regressive form of taxation although they often find that individual products offered by lottery association may vary widely in their regressivity, with instant games generally faring the worst in terms of vertical equity. Freund and Morris $(2005 ; 2006)$ find the presence of lotteries associated with higher levels of income inequality economy-wide.

Others note that when lottery profits are earmarked, a proper accounting of where the spending goes is as important as who buys the tickets when assessing the income equity of the lottery system as a whole. Feehan and Forrest (2007) and Stranahan and Borg (2004) find that wealthy individuals and regions tend to benefit disproportionally from money earmarked towards cultural programs and education, potentially exacerbating the regressivity of the revenue side of lotteries. Gripaios, Bishop and Brand (2010) and Campbell and Finney (2005) note that inequalities in the distribution of lottery proceeds are not limited to income levels but also apply 
to geography and race, although both studies suggest that inequalities in lotteries on the expenditure side are either non-existent or at least less severe than inequalities on the revenue side.

The presence of lotteries may also affect other measures of well-being. On the downside, Kearney (2005b) finds that the presence of a state lottery reduces expenditures on other consumption goods by up to $2.4 \%$, echoing a general concern of Borg, Mason and Shapiro (1991). As is often found in studies of casino gaming, Mikesell and Pirog-Good (1990) find a significant positive correlation between crime rates and the adoption of a lottery. Moreover, Williams and Wood (2007) note that over one-third of gaming revenues in Ontario are generated by a small number of problem gamblers although lottery sales are less prone to abuse than casino gaming or horse racing. On the upside, Skidmore and Tosun (2008) find that the introduction of video lottery spurred general retail sales in West Virginia. Lin and Wu (2010) find that lottery sales are positively correlated with charitable giving allaying fears that the establishment of a "good works" lottery would reduce other types of donations.

\section{Public Finance: Earmarking and Fungibility}

In order to encourage consumers to play (Landry and Price, 2007) and to overcome opposition to state sponsored gambling (Erekson, Platt, Whistler and Ziegert, 1999; Pierce and Miller, 1999; and Ghent and Grant, 2007), governments frequently designate profits from lotteries towards specific agencies. Well over half of state lotteries in the U.S. and some foreign lotteries, including the U.K. Lottery, earmark all or part of the revenues generated for specific government programs, with education being the primary beneficiary (Matheson and Grote, 2008). 
An important empirical question is whether these earmarked funds actually enhance spending dollar-for-dollar for the designated programs or if governments simply substitute earmarked dollars for dollars that would have come from the state's general funds had earmarking not occurred. The extent to which different sources of state funds can substitute for one another is known as "fungibility." Studies of the fungibility of lotteries have focused on educational spending and nearly uniformly find that the introduction of a state lottery increases total educational spending by less than the amount of the new earmarked lottery revenue, suggesting at least some degree of fungibility is present when funds are earmarked for specific state and local programs.

Mikesell and Zorn (1986), Borg and Mason (1988; 1990), and Garrett (2001a) all find that education spending in states that adopted earmarked lotteries for education failed to experience increases in educational spending despite the additional lottery funds. Borg, Mason and Shapiro (1991) find that states with lottery funding earmarked to education have a statistically significantly lower level of spending per-student. Taken as a whole, these works suggest that when lotteries provide a dedicated stream of revenue to education, lawmakers are able to divert general fund resources away from schools, leading to an indirect indication of fungibility.

Spindler (1995), Stark, Wood, and Honeyman (1993), Summers, Honeyman, Wattenbarger and Miller (1995), and Land and Alsikafi (1999) all find that government appropriations to education in a number of different states tend to fall after the introduction of an earmarked lottery. Erekson, DeShano, Platt and Ziegert (2002) and Novarro (2005) conduct cross-sectional, time-series analyses of all 50 states. Erekson et al. (2002) find that the expenditure on education as percentage of general revenues falls as lottery revenues per capita 
rise, indicating that fungibility is a real phenomenon. In addition, for every $\$ 1$ per capita in lottery revenues generated as funding for a state, there is a loss of approximately 1 to $1.5 \%$ of education funding available. Novarro (2005) finds that earmarked lottery profits for education tend to increase spending on education by approximately 79 cents for every $\$ 1$ in lottery profits, while $\$ 1$ in non-earmarked lottery profits tends to increase education spending by only 43 cents on average, findings similar to those of Evans and Zhang (2007). Forrest and Simmons (2003) note that earmarked funds for sport development in the U.K. raise total spending on sport but slightly reduce other local government spending on athletics, but the full degree of fungibility present in earmarked lotteries outside the U.S. is a largely open question.

\section{Public Choice: State Adoption of Lotteries}

Beginning with New Hampshire in 1964, lotteries have spread across the U.S. and Canada over the 50 years to the point where by 2011 governments offered lotteries in all Canadian provinces and 43 of the U.S. states. There are numerous studies examining the factors that influence states to adopt lotteries although the literature on what causes countries adopt lotteries is lacking. Theoretical models of lottery adoption are grounded in the public choice models of regulation, first introduced by Stigler (1971) and Peltzman (1976), in which legislators seek to maximize political support through their legislative decisions. Several contributions provide differing rationales for the prediction that higher incomes should lead to lottery adoption. Filer, Moak and Uze (1988) argue that concern for the regressivity of lotteries will limit their implementation in poor jurisdictions while Martin and Yandle (1990) suggest that the relative political power of the wealthy in rich areas will induce the adoption of lotteries as a means to 
transfer income from the poor to the wealthy. Erekson, Platt, Whistler and Ziegert (1999) argue that rich states will adopt lotteries simply due to the higher potential for lottery revenues.

Empirical studies typically find strong connections between income, poverty levels, and income changes and the adoption of lotteries. Most papers find a significant positive relationship between income and lottery adoption (Filer, Moak and Uze, 1988; Hersch and McDougall, 1989; Martin and Yandle, 1990; Erekson, Platt, Whistler and Ziegert, 1999). Alm, McKee and Skidmore (1993) focus not on income levels but instead trends in income theorizing that a decline in income adds to the fiscal stress of a state, increasing the likelihood of a state to add a lottery.

Existing tax levels, debt, state government spending, and legal restrictions on the ability of a state to collect other forms of revenue all may affect the decision to offer a lottery since fiscal stress can create a motivation for states to seek alternative forms of revenue. Numerous papers find that if tax levels are high, states are more likely to add a lottery as an additional or alternative form of funding (Filer, Moak and Uze, 1988; Alm, McKee and Skidmore, 1993; Jackson, Saurman and Shughart, 1994; Erekson, Platt, Whistler and Ziegert, 1999). One significant deviation from the predicted relationship of variables measuring the fiscal stress in a state is provided by Martin and Yandle (1990), who find a statistically significant negative relationship between per capita taxes paid and the decision to add a lottery although they do find a positive relationship between the per capita debt of a state and the addition of a lottery.

“Tax exporting" is another significant factor in a state's decision to add a lottery. Tax exporting occurs when states earn tax revenues from constituents of other states or conversely lose revenues to other states. If a state is losing out on tax revenues because its residents are purchasing lottery tickets from other states that have already adopted lotteries, this may increase the likelihood of that state adding its own lottery. Numerous studies consider the effect of the 
lottery status of neighboring states on lottery adoption and find statistically significant evidence of this effect (Davis, Filer and Moak, 1992; Alm, McKee and Skidmore, 1993; Jackson, Saurman and Shughart, 1994; Ghent and Grant, 2007). Davis, Filer and Moak (1992) also measure tax exporting in a slightly different manner and find a direct relationship between the number of tourists in a state and a state's decision to add a lottery.

Since adding a lottery is a political decision by legislators and/or voters in a state, it is also necessary to consider organized opposition to lotteries. Many studies find that the percentage of state's population identifying themselves as a member of a conservative religious group (often Baptists) has a statistically significant negative effect on the adoption of lotteries (Hersch and McDougall, 1989; Martin and Yandle, 1990; Jackson, Saurman and Shughart, 1994; Erekson, Platt, Whistler and Ziegert, 1999; Pierce and Miller, 1999). In part to overcome some of the opposition to lotteries, some states have specifically earmarked lottery revenues to be used for specific (and relatively popular) state programs, often education. If earmarking can ease political opposition, states that earmark their funding for education should be more likely to adopt lotteries relative to states that do not intend to earmark lottery revenues, an effect uncovered by Erekson, Platt, Whistler and Ziegert (1999), Pierce and Miller (1999) and Ghent and Grant (2007).

A final factor that is considered in many of the empirical models is the presence of other forms of betting in a state, although the hypothesized direction of the effect is not certain. On the one hand, if a state already allows for other forms of gambling, it is reasonable to assume that it may also be more willing to offer state lottery products to its constituents. On the other hand, other organizations offering gambling products represent an obvious interest group that would typically be opposed to the introduction of a competitor. As a case in point, Nevada, home of the 
largest the casino industry is the U.S., is also one of the few states that does not offer a state lottery. Empirically, Davis, Filer and Moak (1992), Wohlenberg (1992) and Jackson, Saurman and Shughart (1994) all find that the presence of other forms of gambling increases the likelihood of a state adopting a lottery suggesting that outside of Nevada, where casinos and other forms of gambling may be present on a smaller scale, there are less organized interests against competition and the presence of gambling indicates that there would be a demand for additional gambling products like a state lottery.

\section{Conclusions and Suggestions for Future Research}

This paper has explored the existing literature regarding the economics of lotteries. Most research to date has focused on the demand for lottery products and the lottery's impact on public finances and has focused on lotteries in the U.S., Canada, and the U.K. Studies of lotteries in other countries can be found but are much less common, and therefore international lotteries are ripe for additional scholarly work. Even more pressing, while Garrett (2001b) and Matheson and Grote (2009) provide cross-country studies of lotteries, very little work has been done comparing lottery demand, structures, and adoption between different countries. While the existing literature is extensive, many new frontiers yet exist. 


\section{References}

Alm, James, Michael McKee, and Mark Skidmore. 1993. Fiscal Pressure, Tax Competition, and the Introduction of State Lotteries. National Tax Journal 46 (4):463-476.

Atkins, Allen B., and Edward A Dyl. 1995. The Lotto Jackpot: The Lump Sum Versus the Annuity. Financial Practice and Education 5 (2):107-112.

Baker, R. D., and I.G. McHale. 2009. Modelling the Probability Distribution of Prize Winnings in the UK National Lottery: Consequences of Conscious Selection. Journal of the Royal Statistical Society: Series A (Statistics in Society) 172 (4):813-834.

Beenstock, Michael, and Yoel Haitovsky. 2001. Lottomania and Other Anomalies in the Market for Lotto. Journal of Economic Psychology 22 (6):721-744.

Blalock, Garrick, David R. Just, and Daniel H. Simon. 2007. Hitting the Jackpot or Hitting the Skids: Entertainment, Poverty, and the Demand for State Lotteries. American Journal of Economics and Sociology 66 (3):545-570.

Borg, Mary O., and Paul M. Mason. 1988. The Budgetary Incidence of a Lottery to Support Education. National Tax Journal 41 (1):75-85. . 1990. Earmarked Lottery Revenues: Positive Windfalls or Concealed Redistribution Mechanisms? Journal of Education Finance 15 (Winter):289-301.

Borg, Mary O., Paul M. Mason, and Stephen L. Shapiro. 1991. The Economic Consequences of State Lotteries. Westport, CT and London: Greenwood, Praeger.

Brinner, Roger E., and Charles T. Clotfelter. 1975. An Economic Appraisal of State Lotteries. National Tax Journal 28 (4):395-404.

Calcagno, Peter T., Douglas M. Walker, and John D. Jackson. 2010. Determinants of the Probability and Timing of Commercial Casino Legalization in the United States. Public Choice 142 (1-2):69-90.

Campbell, Noel, and R. Zachary Finney. 2005. Mitigating the Combined Distributional Consequences of the Georgia Lottery for Education and the HOPE Scholarship. Social Science Quarterly 86 (3):746-758.

Caudill, Stephen B., Sandra K. Johnson, and Franklin G. Mixon, Jr. 1995. Economies of Scale in State Lotteries: An Update and Statistical Test. Applied Economics Letters 2 (4):115-117.

Chen, Shu-Heng, and Bin-Tzong Chie. 2008. Lottery Markets Design, Micro-structure, and Macro-behavior: An ACE Approach. Journal of Economic Behavior and Organization 76 (2):463-480.

Chernoff, Herman. 1981. How to Beat the Massachusetts Numbers Game. Mathematical Intelligencer 3 (4):166-172.

Ciecka, James, Seth Epstein, and Anthony C. Krautmann. 1996. State Lotteries and Externalities to their Participants. Atlantic Economic Journal:349-360.

Clotfelter, Charles T. 1979. On the Regressivity of State-Operated 'Numbers' Games. National Tax Journal 32 (4):543-548.

Clotfelter, Charles T., and Philip J. Cook. 1987. Implicit Taxation in Lottery Finance. National Tax Journal 40 (4):533-546. 1989. Selling Hope. Cambridge, MA: Harvard University Press. 1990. On the Economics of State Lotteries. Journal of Economic Perspectives 4 (4):105119.

. 1993. The 'Gambler's Fallacy' in Lottery Play. Management Science 39:1521-1525.

Combs, Kathryn L., Jaebeom Kim, and John A. Spry. 2008. The Relative Regressivity of Seven 
Lottery Games. Applied Economics 40 (1-3):35-39.

Conlisk, John. 1993. The Utility of Gambling. Journal of Risk and Uncertainty 6 (3): 255-275.

Cook, Philip J., and Charles T. Clotfelter. 1993. The Peculiar Scale Economies of Lotto. American Economic Review:634-643.

Coughlin, Cletus C., and Thomas A. Garrett. 2009. Income and Lottery Sales: Transfers Trump Income from Work and Wealth. Public Finance Review 37 (4):447-469.

Creigh-Tyte, Stephen, and Lisa Farrell. 2003. Is the UK National Lottery Experiencing Lottery Fatigue? In The Economics of Gambling. New York, NY: Routledge.

Davis, J. Ronnie, John E. Filer, and Donald L. Moak. 1992. The Lottery as an Alternative Source of State Revenue. Atlantic Economic Journal 20 (2):1-10.

DeBoer, Larry. 1985. Administrative Costs of State Lotteries. National Tax Journal 38 (4):479487.

. 1986. Lottery Taxes May Be Too High. Journal of Policy Analysis and Management 5 (3):594-596.

. 1990. Lotto Sales Stagnation: Product Maturity or Small Jackpots? Growth and Change:73-77.

Elliott, Donald S., and John C. Navin. 2002. Has Riverboat Gambling Reduced State Lottery Revenue? Public Finance Review 30 (3):235-247.

Erekson, O. Homer, and Kimberly M. DeShano, Glenn Platt, and Andrea L. Ziegert. 2002. Fungibility of Lottery Revenues and Support of Public Education. Journal of Education Finance 28 (2):301-311.

Erekson, O. Homer, Glenn Platt, Christopher Whistler, and Andrea L. Ziegert. 1999. Factors Influencing the Adoption of State Lotteries. Applied Economics 31 (7):875-884.

Evans, Willam N. and Ping Zhang. 2007. The Impact of Earmarked Lottery Revenue on K-12 Educational Expenditures. Education Finance and Policy 2 (1):40-73.

Farrell, Lisa, Roger Hartley, Gauthier Lanot, and Ian Walker. 2000. The Demand for Lotto: The Role of Conscious Selection. Journal of Business and Economic Statistics 18 (2):228241.

Farrell, Lisa, Edgar Morgenroth, and Ian Walker. 1999. A Time Series Analysis of UK Lottery Sales: Long and Short Run Price Elasticities. Oxford Bulletin of Economics and Statistics 61 (4):513-526.

Farrell, Lisa, and Ian Walker. 1997. It could be you! But what's it worth? The welfare gain from Lotto. In Institute for Fiscal Studies Working Papers.

- 1999. The Welfare Effects of Lotto: Evidence from the UK. Journal of Public Economics 72 (1):99-120.

Feehan, Patrick, and David Forrest. 2007. Distribution of UK National Lottery Grants across Local Authority Areas. Applied Economic Letters 14 (4-6):361-365.

Filer, John E., Donald L. Moak, and Barry Uze. 1988. Why Some States Adopt Lotteries and Others Don't. Public Finance Quarterly 16 (3):259-283.

Forrest, David, and Dika Alagic. 2007. The History of a Lottery Game that was Seldom Won. Journal of Gambling Business and Economics 1:57-68.

Forrest, David, O. David Gulley, and Robert Simmons. 2000a. Elasticity of Demand for UK National Lottery Tickets. National Tax Journal 53 (4):853-863.

-2000b. Testing for Rational Expectations in the UK National Lottery. Applied Economics 32 (3):315-326. 2004. Substitution between Games in the UK National Lottery. Applied Economics 36 
(7):645-651.

- 2010. The Relationship between Betting and Lottery Play. Economic Inquiry 48 (1):2638.

Forrest, David, Levi Perez, and Rose Baker. 2010. Evaluating the Effects of Game Design on Lotto Sales: A Case Study from Spain. Journal of Gambling Business and Economics 4 (2):1-19.

Forrest, David, and Robert Simmons. 2003. Sport and Gambling. Oxford Review of Economic Policy 19 (4):598-611.

Forrest, David, Robert Simmons, and N. Chesters. 2002. Buying a Dream: Alternative Models of Demand for Lotto. Economic Inquiry 40 (3):485-496.

Freund, Elizabeth A., and Irwin L. Morris. 2005. The Lottery and Income Inequality in the States. Social Science Quarterly 86 (Supplement):996-1012. . 2006. Gambling and Income Inequality in the States. Policy Studies Journal 34 (2):265276.

Friedman, Milton, and Leonard J. Savage. 1948. The Utility Analysis of Choices Involving Risk. Journal of Political Economy 56:279-304.

Garrett, Thomas. 2001a. An International Comparison and Analysis of Lotteries and the Distribution of Lottery Expenditures. International Review of Applied Economics 15 (2):213-227. . 2001b. Earmarked Lottery Revenues for Education: A New Test of Fungibility. Journal of Education Finance 26 (3): 219-238.

Garrett, Thomas A., and Cletus C. Coughlin. 2009. Inter-temporal Differences in the Income Elasticity of Demand for Lottery Tickets. National Tax Journal 62 (1):77-99.

Garrett, Thomas A., and Thomas L. Marsh. 2002. The Revenue Impacts of Cross-Border Lottery Shopping in the Presence of Spatial Autocorrelation. Regional Science and Urban Economics 32 (4):501-519.

Garrett, Thomas A., and Russell S. Sobel. 1999. Gamblers Favor Skewness, Not Risk: Further Evidence from United States' Lottery Games. Economics Letters 63 (1):85-90.

- 2004. State Lottery Revenue: The Importance of Game Characteristics. Public Finance Review 32 (3):313-330.

Geronikolaou, George, and George Papachristou. 2007. On the Demand for Lotteries in Greece. International Journal of Business and Economics 6 (3):255-259.

Ghent, Linda S., and Alan P. Grant. 2007. Are Voting and Buying Behavior Consistent? Evidence from the South Carolina Education Lottery. Public Finance Review 35 (6):669688.

Gripaios, Peter, Paul Bishop, and Steven Brand. 2010. A Lottery within a Lottery? An Examination of the Distribution of Lottery Funds in England. Applied Economics 42 (13):63-71.

Grote, Kent R., and Victor A. Matheson. 2006. Dueling Jackpots: Are Competing Lotto Games Complements or Substitutes? Atlantic Economic Journal 34 (1):85-100.

. 2006. In Search of a Fair Bet in the Lottery. Eastern Economic Journal 32 (4):673-684.
. 2007. Examining the 'Halo Effect' in Lotto Games. Applied Economic Letters 14 (46):307-310.

Gulley, O. David, and Frank A. Scott, Jr. 1989. Lottery Effects on Pari-mutual Tax Revenues. National Tax Journal 42 (1):89-93. . 1993. The Demand for Wagering on State-Operated Lotto Games. National Tax Journal 
$46(1): 13-22$.

Guryan, Jonathan, and Melissa S. Kearney. 2006. Lucky Stores, Gambling and Addiction:

Empirical Evidence from State Lottery Sales. Atlantic Economic Journal:85-100. . 2008. Gambling at Lucky Stores: Empirical Evidence from State Lottery Sales. American Economic Review 98 (1):458-473.

- 2010. Is Lottery Gambling Addictive? American Economic Journal: Economy Policy 2 (3):90-110.

Hauser-Rethaller, Ursula, and Ulrich Konig. 2002. Parimutuel Lotteries: Gamblers' Behavior and the Demand for Tickets. German Economic Review 3 (2):223-245.

Heberling, Michael. 2002. State Lotteries: Advocating a Social Ill for the Social Good. Independent Review 6 (4):597-606.

Hersch, Philip L., and Gerald S. McDougall. 1989. Do People Put Their Money Where Their Votes Are? The Case of Lottery Tickets. Southern Economic Journal 56 (1):32-38.

Humphreys, Brad R., and Victor A. Matheson. 2012. Booms, Busts, and Gambling: Can Gaming Revenues Reduce Budget Volatility? In Boom and Bust Again, edited by R. Ascah and D. Ryan. Alberta, Canada: University of Alberta Press.

Jackson, John D., David S. Saurman, and William F. Shughart, II. 1994. Instant Winners: Legal Change in Transition and the Diffusion of State Lotteries. Public Choice 80 (3-4):245263.

Jackson, Raymond. 1994. Demand for Lottery Products in Massachusetts. Journal of Consumer Affairs 28 (2):313-325.

Kearney, Melissa S. 2005a. The Economic Winners and Losers of Legalized Gambling. National Tax Journal 58 (2):281-302. . 2005b. State Lotteries and Consumer Behavior. Journal of Public Economics 89 (1112):2269-2299.

Kitchen, Harry, and Scott Powells. 1991. Lottery Expenditures in Canada: A Regional Analysis of Determinants and Incidence. Applied Economics 23 (12):1845-1852.

Krautmann, Anthony C., and James E. Ciecka. 1993. When are State Lotteries a Good Bet? Eastern Economic Journal 19 (2):157-64.

Laitner, John. 1999. Means-Tested Public Assistance and the Demand for State Lottery Tickets. Economic Dynamics 2 (1):273-290.

Land, Vance Q., and Majeed H. Alsikafi. 1999. A Lottery's Impact on Instructional and Noninstructional Expenditures and Unrestricted Revenues for Education. Journal of Education Finance 25 (2):149-174.

Landry, Craig E., and Michael K. Price. 2007. Earmarking Lottery Proceeds for Public Goods: Empirical Evidence from U.S. Lotto Expenditures. Economics Letters 95 (3):451-455.

Layton, Allan, and Andrew Worthington. 1999. The Impact of Socio-economic Factors on Gambling Expenditure. International Journal of Social Economics 26 (1-2-3):430-440.

Lee, Chuan, Chin-Tsai Lin, and Chien-Hua Lai. 2010. Jackpot Promotion Model for Taiwan Lotto. Applied Economics 42 (4-6):797-801.

Lin, Eric S., and Shih-Ying Wu. 2007. Lottery Expenses and Charitable Contributions--Taiwan's Experience. Applied Economics 39 (16-18):2241-2251.

Livernois, John R. 1986. The Taxing Game of Lotteries in Canada. Canadian Public Policy 12 (4):622-627.

Markowitz, Harry M. 1952. The Utility of Wealth. Journal of Political Economy 60 (2):151-158. Martin, Robert, and Bruce Yandle. 1990. State Lotteries as Duopoly Transfer Mechanisms. 
Public Choice 64 (3):253-264.

Mason, Paul M., Jeffrey W. Steagall, and Michael M. Fabritius. 1997. The Elasticity of Demand for Lotto Tickets and the Corresponding Welfare Effects. Public Finance Review 25 (5).

Matheson, Victor A. 2001. When are State Lotteries a Good Bet? (Revisited). Eastern Economic Journal 27 (1):55-70.

Matheson, Victor A., and Kent R. Grote. 2003. Jacking up the Jackpot: Are Lotto Consumers Fooled by Annuity Payments? Public Finance Review 31 (5):550-567. . 2004. Lotto Fever: Do Lottery Players Act Rationally around Large Jackpots? Economics Letters 83 (2):233-237.

- 2005. Rationality and Efficiency in Lotto Games. In Information Efficiency in Financial and Betting Markets edited by L. Vaughan Williams. New York, NY: Cambridge University Press. . 2007. Gamblers' Love for Variety and Substitution among Lotto Games. Journal of Gambling Business and Economics.

- 2008. U.S. Lotto Markets. In Handbook of Sports and Lottery Markets edited by D. B. Hausch and W. T. Ziemba. New York, NY: North-Holland.

Mikesell, John L. 1987. The Effect of Maturity and Competition on State Lottery Markets. Journal of Policy Analysis and Management 6 (2):251-253.

- 1989. . A Note on the Changing Incidence of State Lottery Finance. Social Science Quarterly 70 (2):513-521.

- 1994. State Lottery Sales and Economic Activity. National Tax Journal 47 (1):165-171. Mikesell, John L. and Maureen A. Pirog-Good. 1990. State Lotteries and Crime: The Regressive Revenue Producer Is Linked with a Crime Rate Higher by 3 Percent. American Journal of Economics and Sociology 49 (1):7-19.

Mikesell, John L., and C. Kurt Zorn. 1986. State Lotteries as Fiscal Savior or Fiscal Fraud: A Look at the Evidence. Public Administration Review 46:311-320.

- 1987. State Lottery Sales: Separating the Influence of Markets and Game Structure. Growth and Change 18 (4):10-19.

-------. 1988. State Lotteries for Public Revenue. Public Budgeting and Finance 8 (1):38-47.

Miller, James D., and Matthew R. Morey. 2003. Power Markets: Transferring Systematic Risk to Lottery Players. Public Budgeting and Finance 23 (2):118-133.

Novarro, Neva K. 2005. Earmarked Lottery Profits: A Good Bet for Education Finance? Journal of Education Finance 31 (1):23-44.

Oster, Emily. 2004. Are All Lotteries Regressive? Evidence from the Powerball. National Tax Journal 57 (2):179-187.

Papachristou, George. 2004. The British Gambler's Fallacy. Applied Economics 36 (18):20732077.

- 2006. Is Lottery Demand Elasticity a Reliable Marketing Tool? Evidence from a Game Innovation in Greece. International Review of Economics and Business 53 (4):627-640.

—. 2009. Scale Economies of Lotto Once More. Applied Economic Letters 16 (1-3):319323.

Papachristou, George, and Dimitri Karamanis. 1998. Investigating Efficiency in Betting Markets: Evidence from the Greek 6/49 Lotto. Journal of Banking and Finance 22:1597-1615.

Peltzman, Sam. 1976. Towards a More General Theory of Regulation? Journal of Law and Economics 19 (2):211-240.

Pierce, Patrick A., and Donald E. Miller. 1999. Variations in the Diffusion of State Lottery 
Adoptions: How Revenue Dedication Changes Morality Politics. Policy Studies Journal 27 (4):696-706.

Purfield, Catriona, and Patrick Waldron. 1999. Gambling on Lotto Numbers: Testing for Substitutability or Complementarity Using Semi-weekly Turnover Data. Oxford Bulletin of Economics and Statistics 61 (4):527-544.

Quiggin, John. 1991. On the Optimal Design of Lotteries. Economica 59 (229):1-16.

Rodgers, William M., and Charles Stuart. 1995. The Efficiency of a Lottery as a Source of Public Revenue. Public Finance Quarterly 23 (2):242-254.

Scoggins, John F. 1995. The Lotto and Expected Net Revenue. National Tax Journal 48 (1):6170.

Scott, Frank, and John Garen. 1994. Probability of Purchase, Amount of Purchase, and the Demographic Incidence of the Lottery Tax. Journal of Public Economics 54 (1):121-143.

Scott, Frank A., Jr., and O. David Gulley. 1995. Testing for Efficiency in Lotto Markets. Economic Inquiry 33 (2):175-188.

Siegel, Donald, and Gary Anders. 2001. The Impact of Indian Casinos on State Lotteries: A Case Study of Arizona. Public Finance Review 29 (2):139-147.

Simon, Jonathan. 1999. An Analysis of the Distribution of Combinations Chosen by UK National Lottery Players. Journal of Risk and Uncertainty 17 (3):243-276.

Skidmore, Mark, and Mehmet Serkan Tosun. 2008. Do New Lottery Games Stimulate Retail Activity? Evidence from West Virginia Counties. Journal of Regional Analysis and Policy 38 (1):45-55.

Spindler, Charles J. 1995. The Lottery and Education: Robbing Peter to Pay Paul? Public Budgeting and Finance 15 (3):54-62.

Stark, Steven R., R. Craig Wood, and David S. Honeyman. 1993. The Florida Education Lottery: Its Use As a Substitute for Existing Funds and Its Effects on the Equity of School Funding. Journal of Education Finance 18 (Winter):231-242.

Steinnes, Donald N. 1998. Have Native American Casinos Diminished Other Gambling in Minnesota? An Economic Answer Based on Accessibility. Regional Analysis and Policy 28 (1):18-32.

Stigler, George J. 1971. The Theory of Economic Regulation. Bell Journal of Economics and Management Science 2 (1):3-21.

Stranahan, Harriet A. and Mary O. Borg. 2004. Some Futures Are Brighter than Others: The Net Benefits Received by Florida Bright Futures Scholarship Recipients. Public Finance Review 32 (1):105-126.

Suits, Daniel B. 1977. Gambling Taxes: Regressivity and Revenue Potential. National Tax Journal 30 (1):19-35. . 1979. Economic Background for Gambling Policy. Journal of Social Issues 35 (3):4361.

Summers, Susan R., David S. Honeyman, James L. Wattenbarger, and M. David Miller. 1995. An Examination of Supplantation and Redistribution Effects of Lottery Allocations To a Community College System. Journal of Education Finance 21 (Fall):236-253.

Szakmary, Andrew, and Carol Matheny Szakmary. 1995. State Lotteries as a Source of Revenue: A Re-examination. Southern Economic Journal 61 (4).

Terrell, Dek. 1994. A Test of the Gambler's Fallacy: Evidence from Pari-mutuel Games. Journal of Risk and Uncertainty 8 (3):309-317.

Thaler, Richard H., and William T. Ziemba. 1988. Parimutuel Betting Markets: Racetracks and 
Lotteries. Journal of Economic Perspectives 2 (2):161-174.

Thiel, Stuart E. 1991. Policy, Participation and Revenue in Washington State Lotto. National Tax Journal 44 (2):225-235.

Vasche, Jon David. 1985. Are Taxes on Lotteries Too High? Journal of Policy Analysis and Management 4 (2):269-271.

Vaughan Williams, Leighton. 2005a. Semi-strong and Strong Form Information Efficiency in Betting Markets. In Information Efficiency in Financial and Betting Markets, edited by L. Vaughan Williams. Cambridge: Cambridge University Press.

. 2005b. Weak Form Information Efficiency in Betting Markets. In Information Efficiency in Financial and Betting Markets, edited by L. Vaughan Williams. Cambridge: Cambridge University Press.

Vrooman, David H. 1976. An Economic Analysis of the New York State Lottery. National Tax Journal 29 (4):482-489.

Walker, Douglas M., and John D. Jackson. 1999. State Lotteries, Isolation and Economic Growth in the U.S. Review of Urban and Regional Development Studies 11 (3):187-192.

—. 2008. Do U.S. Gambling Industries Cannibalize Each Other? Public Finance Review 36 (3):308-333.

Walker, Ian. 1998. Lotteries: Determinants of Ticket Sales and the Optimal Payout Rate. Economic Policy: A European Forum 27:357-392.

Walker, Ian, and Juliet Young. 2001. An Economist's Guide to Lottery Design. Economic Journal 111 (475):700-722.

Weinbach, Andrew P., and Rodney J. Paul. 2008. Running the Numbers on Lotteries and the Poor: An Empirical Analysis of Transfer Payment Distribution and Subsequent Lottery Sales. Atlantic Economic Journal 36 (3):333-344.

Williams, Robert J., and Robert T. Wood. 2007. The Proportion of Ontario Gambling Revenue Derived from Problem Gamblers. Canadian Public Policy 33 (3):367-387.

Wisman, Jon D. 2006. State Lotteries: Using State Power to Fleece the Poor. Journal of Economic Issues 40 (4):955-966.

Wohlenberg, Ernest H. 1992. Recent U.S. Gambling Legalization: A Case Study of Lotteries. Social Science Journal 29 (2):167-184.

Ziemba, William T., Shelby L. Brumelle, Antoine Gautier, and Sandra L. Schwartz. 1986. Dr. Z's 6/49 Lotto Guidebook. Vancouver: Dr. Z's Investment, Inc. 